Jurnal Interpretasi Hukum |ISSN: 2746-5047

Vol. 2, No. 2 - Agustus 2021, Hal. 241-245 | Tersedia online di

https://www.ejournal.warmadewa.ac.id/index.php/juinhum

DOI: https://doi.org/10.22225/juinhum.2.2.3411.241-245

\title{
PERTIMBANGAN HAKIM DALAM PUTUSAN PERKARA PENADAHAN MOBIL
}

\author{
Ida Bagus Mayun Andika Putra, I Nyoman Gede Sugiartha, I Nyoman Subarnia \\ Fakultas Hukum, Universitas Warmadewa, Denpasar-Bali, Indonesia \\ wigusmayun25@gmail.com, nyomansugiartha14@gmail.com, doktorsubamia@gmail.com
}

\begin{abstract}
Abstrak
Kasus dalam penadahan kendaraan sering terjadi mengingat meningkatnya jumlah produksi kendaraan yang makin menanjak. Seseorang melakukan kejahatan pencurian kendaraan bermotor dikarenakan ingin memiliki namun ekonominya tidak memungkinkan untuk membeli secara resmi. Maka salah satu upaya dalam merealisasikan hal ini yaitu melalui penadahan dikarenakan harganya jauh lebih murah dari harga resminya. Tujuan penelitian ini untuk mengungkap pertimbangan hakim dalam putusan perkara penadahan mobil serta sanksi pidana pelaku tindak pidana penadahan mobil. Metode penelitian yang digunakan yaitu metode penelitian normatif dengan pendekatan konseptual dan pendekatan kasus. Adapun sumber bahan hukum yang digunakan berupa sumber hukum primer dan sekunder. Teknik pengumpulan bahan hukum di lakukan dengan cara mencatat, mengutip, membaca, maupun meringkas literatur yang mengacu terhadap pertimbangan hakim dalam putusan perkara penadahan mobil. Setelah bahan hukum dikumpulkan, selanjutnya di analisis denga sistematis. Hasil penelitian mengungkapkan bahwa pasal 480 KUHP digunakan sebagai sanksi pidana penadahan apabila terdakwa terbukti bersalah.
\end{abstract}

Kata Kunci: Penadahan, Pertimbangan Hakim, Sanksi Penadahan

\begin{abstract}
Cases in vehicle catching often occur given the increasing number of vehicle production increases. Someone commits the crime of motor vehicle theft because they want to own it, but the economy does not allow it to buy legally. One of the efforts to realize this is through restructuring because the price is much cheaper than the official price. The purpose of this research is to reveal the judges' considerations in the decision of car arresting cases and the criminal sanctions for car arresting offenders. The research method used is a normative research method with a conceptual approach and a case approach. The sources of legal materials used are primary and secondary sources of law. The technique of collecting legal materials is done by recording, quoting, reading, and summarizing the literature that refers to the judge's consideration in the decision of the car arresting case. After the legal materials are collected, they are analyzed systematically. The results of the study reveal that Article 480 of the Criminal Code is used as a criminal sanction for detention if the defendant is found guilty.

Keywords: Detention, Judge's Consideration, Detention Sanctions
\end{abstract}

\section{PENDAHULUAN}

Keadaan masa sekarang ini pemerintah sedang fokus melakukan pembangunan dibidang hukum, sebagaimana untuk memberikan wujud reformasi dari hukum itu sendiri. Untuk dapat menciptakan ketertiban, keamanan dan kesejahteraan di kalangan masyarakat. Kejahatan terhadap harta benda sering terjadi dilingkungan masyarakat, seperti kejahatan harta benda pencurian, perampokan, penipuan, penggelapan, atau, penadahan (Prasetyo, 2010).

Diantara kasus kejahatan yang sering dijumpai pada saat ini, yaitu kejahatan penadah khususnya terhadap kendaraan bermotor, maupun kendaraan roda empat yang menjadi salah satu kejahatan yang sering dijumpai sampai saat ini. Pembeli kendaraan bermotor, maupun kendaraan roda empat hasil pencurian disebut dikatakan sebagai penadah, karena si pembeli sudah mengetahui barang yang dibeli merupakan barang dari pencurian (Rukmini, 2009).

Pada kriminal penadahan, pelaku sudah sepatutnya mengira maka barang yang di peroleh tersebut menggambarkan hasil kejahatan, sebagai contoh mobil yang diperjualkan tidak dilengkapi dengan surat sah seperti surat kendaraan bermotor (STNK) dan buku pemilik kendaraan bermotor (BPKB). Dengan reaksi sosial ini, maka semakin banyak pula terlihat pada saat permasalahannya, kejahatan yang sangat sering meningkat secara hukurn, dan pengadilan hukum dapat memperlihatkan individu serta seluruh masyarakat dalarn alternatif pilihan yang menyesuaikan serta penyimpangan. 
Sedangkan dalam bentuk menyimpang atau pelanggar serius sifatnya yaitu pelanggar hukum yang bisa dikatakan sebagai penjahat. Pada situasi saat ini kejadian seperti ini dapat dimasukan kedalam tindak pidana penadahan, karena kejadian perbuatan tersebut telah mendorong seseorang untuk berbuat kejahatan, atau istilah lain dapat dikatakan sebagai pertolongan jahat yang dimana sudah diatur didalam pasal 480 KUHP.

Pada dasarnya dalam mengungkap tindak pidana penadahan tidak mengharuskan untuk menghukum atau menunggu pelaku tindak pidana pencurian terlebih dahulu karena awal mula terjadinya tindak pidana penadahan ini bermula dari tindak pidana pencurian (Khoirunnisak et al., 2017). Lebih lanjut menurut Lestiyana \& Sudarti (2020) dengan menerapkan jenis dakwaan tunggal yakni Pasal 480 ayat (1) KUHP sudah sesuai dikarenakan perbuatan dari masing-masing terdakwa memang hanya tertuju pada satu tindak pidana saja yaitu penadahan yang merujuk Pasal 480 ayat (1) KUHP. Tindak pidana yang biasa terjadi adalah tindak pidana penadahan kendaraan yang merupakan hasil pencurian. Sebagaimana yang telah diatur di dalam Buku II Bab XXX KUHP mengenai tindak pidana penadahan yang dimana salah satu unsur kegiatan ini yang biasa dibuktikan oleh Jaksa Penuntut Umum pada praktik persidangan adalah unsur culpa, yang berarti bahwa pelaku penadahan harus dapat menyangka asal barang tersebut dari kejahatan (Mamahit, 2017).

Berdasarkan uraian diatas, tujuan penelitian ini untuk mengungkap pertimbangan hakim dalam putusan perkara penadahan mobil serta sanksi pidana pelaku tindak pidana penadahan mobil.

\section{METODE PENELITIAN}

Penelitian ini menggunakan penelitian hukum secara normatif, dimana mengacu kepada studi kepustakaan di bidang hukum, dengan menggunakan pendekatan masalah secara konseprual dan pendekatan kasus. Sumber hukum yang digunakan berupa sumber hukum primer dengan menggunakan yakni bahan hukum primer berpedoman terhadap undang-undang dan keputusan yang mengikat dan bahan hukum sekunder yang diperoleh melalui jurnal, buku hukum, serta internet yang memuat mengenai pertimbangan hakim dalam putusan perkara penadahan mobil. Teknik pengumpulan bahan hukum Hal ini di lakukan dengan cara mencatat, mengutip, membaca, maupun meringkas literatur yang mengacu terhadap pertimbangan hakim dalam putusan perkara penadahan mobil. Setelah data dikumpulkan, kemudian setiap bahan hukum dianalisis dalam bentuk kalimat yang teratur, logis, dan efektif sehingga mudah untuk memahami hasil analisis, bahan buku yang dipergunakan untuk memilih yang sesuai dengan topik dari penelitian skripsi yang mana akan di analisis dengan sistematis dan mengaitkannya dengan bahan hukum.

\section{HASIL DAN PEMBAHASAN}

\section{Pertimbangan Hakim dalam Putusan Perkara Penadahan Mobil}

Pertimbangan hakim adalah merupakan posisi yang paling penting dalam mengarahkan nilai dari hasil keputusan hakim. Dimana putusan tersebut berisi keadilan, dan ketentuan hukum. disamping itu juga terdapat fungsi bagi pihak yang bersangkutan, sehingga pertimbangn hakim tersebut harus disikapi dengan baik, cermat, dan teliti. Hakim memeriksa suatu kasus juga perlu memerlukan pembuktian, dari hasil pembuktian itu akan diambil sebagai bahan untuk mernutuskan suaru kasus tersebut Dimana dalam pembuktian ini adalah tahap yang sangat relevan, dimana dalam pemeriksaan persidangan, pembuktian bertujuan agar mendapatkan suatu kepastian untuk suatu peristiwa dan fakta yang diajukan tersebut pasti terjadi, agar mendapatkan putusan hakim yang berbenar.

Hakim dalam melaksanakan rugas untuk merujuk suatu kejadian, khususnya perkara pidana yang sedikit ditemui, bahwa untuk merujuk suatu perkara tersebut menghabiskan waktu yang sangat panjang, bisa sampai berrninggu-minggu, bahkan sampai berbulan-bulan, dan mungkin bisa sampai bertahun-tahun lamanya, baru bisa terselesaikan suatu perkara dipengadilan. Pokok kekuasaan kehakiman diatur dalam undang-undang dasar negara republik indonesia, Bab IX pasal 24 dan 25 serta di dalam undang-undang Nomor 48 tahun 2009, menjamin adanya kekuasaan kehakiman yang bebas. Hakim juga memerlukan alat bukti untuk menunjang para pemeriksa, dalam menyelidiki suatu kasus, agar hakim dapat mempertimbangkan hasil dari alat bukti tersebut. Dengan adanya alat bukti maka pemeriksa dapat mendetail dan dapat menyelesaikan perkara pidana. Menurut Hamzah (2011) Alat bukti yang sah terdapat pada pasal 184 KUHP yakni:

a. Penjelasan saksi

b. Penjelasan ahli 
c.Surat

d. Petunjuk, dan

e. penjelasan terdakwa

Namun keadaan saat ini ada saja kelakuan saksi yang memberikan informasi keterangan palsu, mungkin ada kedekatan, atau keluarga dengan terdakwa. Ada Kalanya hakim percaya dengan keterangan palsu tersebut yang disampaikan oleh saksi dalam persidangan tersebut. akan tetapi masih banyak terdapat pembuktian yang salah yakni, keterangan palsu dari seorang saksi, surat dan bukti lainnya tidak sesuai dengan fakta yang ada. Dengan memberikan keterangan palsu tersebut bisa saja hukuman yang dijatuhkan oleh hakim untuk pelaku diringankan (Soesilo, 1984).

\section{Sanksi Pidana Pelaku Tindak Pidana Penadahan Mobil}

Tindak pidana penadahan adalah tindak pidana yang tidak bisa bertumpu mandiri, karena tindak pidana yang didahulukan dengan tindak pidana asal. Karena tindak pidana ini merupakan tindak pidana berantai dimana harus diutamakan dengan perbuatan karena itulah seorang melakukan kriminal, dan barang hasil kriminal tersebut ada yang dipakai seorang diri, dan ada juga dijual memperuntukan menarik keuntungan (Lamintang, 1997).

Pertimbangan hakim dalam menetukan pertanggungjawaban pidana terhadap seseorang yang membeli barang hasil kejahatan ditinjau dari unsur obyektif maupun subyektif dari tindak pidana penadahan itu sendiri, yang mana hal tersebut dapat dibuktikan dari penilaian alat-alat bukti sah yang dihadirkan dalam persidangan, yang dinilai oleh hakim sehingga memperoleh keyakinan dalam menentukan pertanggungjawaban pidananya (Putra et al., 2016).

Mengenal makna penadah ini, untuk saat ini tidak ada ringkasan yang jelas mengenai keterangan sah sebagai pedoman para ahli hukum pidana. Hanya mencangkup tindak pidana penadahan tersebut seperti komponen dari kejahatan pertolongan jahat. Menurut prof.Satochid Kartanegara, penadahan disebut juga sebagai tindak pidana pemudah, karena perbuatan menadah dapat menghasut atau membantu orang lain untuk melakukan kejahatan (Lamintang, 2009).

Unsur-unsur tindak pidana penadahan dalam pasal 480 ayat 1 KUHP ada dua ringkasan kejahatan penadahan, ringkasan yang kesaru memiliki unsur-unsur berikut:

a. Unsur-unsur objektif, yaitu :

1) kopen atau membayar

2) Buren atau menyewakan

3) Inruilen Atau menukarkan

4) In pand nemenz atau menjaminkan

5) Als geschenk anemen atau memiliki sebagai hadiah

6) Uit winst jaga atau dibantu oleh maksud untuk menaikan keuntungan

7) verokepen atau memasarkan

8) Verhuren Atau menyewakan

9) In pad geven arau menjaminkan

10) Vervoeren atau mengangkat

11) Bewarenz atau menguatkan

12) Verbergen atau menutup-nutupi

b. Unsur-unsur subjektif, yaitu :

1) Yang ia ketahui atau waarvan hij weet

2) Yang secara patut harus dapat ra duga atau warn hij redelijkerwijs moet vermoeden.

Sementara itu dalam ayat 2 menyatakan penadahan terdiri dari unsur-unsur berikut:

a. Unsur-unsur objektif

1) Perilaku yang tujuannya untuk mendapatkan penghasilan dari

2) Objeknya adalah hasil dari suatu barang

3) Yang diperolehnya dari suatu kejahatan

b. Unsur-unsur subjektif

1) Yang diketahuinya, atau

2) Patut menduga barang tersebut dari hasil kejahatan

Untuk mendapatkan seorang pelaku telah pasti memenuhi unsur yang diketahui sebagai halnya dapat ditafsirkan berdasarkan uraian diatas baik penuntut umum dan hakim mesti pandai memperlihatkan di persidangan untuk memeriksa dan mengadili pelaku: 
a. Bahwa pelaku sudah mengira yakni, benda tersebut telah didapatkan dari hasil pencurian

b. Bahwa pelaku mempunyai tujuan untuk melakukan perbuatannya dimana didakwakannya oleh penuntut umum

c. Bahwa pelaku mempunyai tujuan dan bermaksud teruntuk melakukan kegiatan yang terbukti oleh penuntut umum, karena mendorong hasrat untuk rnendapatkan keuntungan.

Maka dari itu sanksi tindak pidana penadahan mobil terdapat 3 sanksi pidana yakni:

a. Penadahan biasa

Dimana penadahan ini rnerupakan tindak pidana yang tidak ada hal yang mendahulukan dalam ancaman pidana, karena kegiatan penadahan biasa ini dikenai sanksi penjara selama empat (4) tahun, dan dikenai denda sebesar Rp.900 (sembilan ratus rupiah). seperti itulah isi pasal dari pasal 480 KUHP.

b. Penadahan Ringan

Penadahan ringan ini merupakan penadahan yang sangat ringan karena di dalam penadahan ini yang ditahan ialah barang bukti yang ditemukan dari hasil kejahatan ringan, jika barang bukti tersebut didapatkan dari salah satu kejahatan yang diatur didalam pasal 364,373, dan 379 KUHP. Maka bersalah melaksanakan penadahan ringan dengan ancaman hukuman penjara paling lama tiga (3) bulan dan pidana denda paling banyak Rp.900 (sembilan ratus rupiah). sesuai dalam pasal 482 KUHP. c. Penadahan kebiasaan atau pemberatan

Dimana pelaku penadahan diancam lebih berat dari pada penadahan bisa dan penadahan ringan karena penadahan ini dikatakan tidak hanya dilakukan sekali saja, namun terus-menerus, dan dikatakan sebagai mata pencahariannya, walaupun pelaku sudah mengetahui perbuatan yang ia lakukan dilarang dan telah melanggar hukurn, yang dimana pelaku akan diberikan ancaman kurungan penjara selama 7 (tujuh) tahun lamanya.

\section{SIMPULAN DAN SARAN}

\section{Simpulan}

Majelis Hakim mempertimbangkan atas dasar bukti hukum yang terkuak di persidangan melalui penjelasan saksi, barang bukti,maupun penjelasan pelaku itu sendiri, berdasarkan putusan nomor 647/Pid.B/2018/PN Jkt.Utr. Berdasarkan fakta terdakwa melakukan tindak pidana penadahan dengan modus untuk mendapatkan keuntungan, selanjutnya hakim mepertimbangkan pertama-tama kejadian yang memberatkan dan meringankan pelaku sebelum hakim memberikan keputusan terhadap pelaku. Seperti Pelaku merugikan orang lain, Pelaku meresahkan masyarakat atau keadaan yang meringankan seperti Pelaku belum pernah dihukum, Pelaku mengakui dengan terus terang perbuatannya dan sopan di persidangan, Pelaku menyesali perbuatannya, Pelaku masih dibawah umur. Karena semua unsur dari pasal 480 ayat I sudah terpenuhi, maka terdakwa dinyatakan terbukti secara sah dan menyakinkan melakukan ti ndak pidana penadahan mobil, dan dihukurn seringan-ringannya dengan pidana penjara 10 (sepuluh) bulan, dan dikenakan biaya perkara sebesar Rp. 5.000.00 (lima ribu rupiah). Sanksi pidana penadahan mobil, yakni perbuatan yang merupakan pertolongan jahat dimana pelaku mernbantu menjual hasil barang dari kejahatan yang dimana guna unruk mendapatkan keunrungan, dan dijadikan sebagai mata pencaharian. Kasus tindak pidana penadahan dapat dikenakan sanksi penjara selama 4 (empat) tahun, dan dikenakan biaya perkara sebesar Rp. 900 (sembilan ratus rupiah) barangsiapa membeli, menyewa, menukar, menerima gadai, menukarkan, menggadaikan, mengangkut, menyimpan, atau menyembunyikan sesuatu benda, yang diketahui atau sepatutnya harus diduga bahwa dari hasil kejahatan. Seperti itu isi dari pasal 480 ayat I. Rancangan Undang-Undang KUHP.

\section{Saran}

Diharapkan hakim kedepannya dapat tegas dalam mengambil keputusan dan memberikan saksi yang sesuai bagi pelaku tindak pidana penadahan karena perilaku tersebut dapat merugikan masyarakat dan sangat merugikan masyarakat, oleh karena itu penerapan pidana yang sangat ringan yang diputuskan oleh majelis hakim sama sekali tidak memberikan efek bagi pelaku tindak pidana penadahan mobil. Hakim juga harus ikut mendukung program pemerintah untuk menghilangkan aksi kejahatan penadahan yang bisa saja meresahkan masyarakat dengan cara penyuluhan terhadap masyarakat yang belum memahami apa itu penadahan. Diharapkan kedepannya sanksi pidana penadahan perlu dikaji ulang dan diperbaiki kembali mengingat pasal 480 KUHP tersebut masih sangat kurang tepat, atau 
bisa dikatakan masih sangat ringan, karena sanksi tersebut masih terlihat sangat rendah terutama di bagian denda tersebut masih terlihat sangat sedikit, mengingat kerugian yang dihasilkan bisa sampai puluhan juta, bahkan sampai ratusan juta dan tidak sesuai dengan denda yang diberikan sebesar Rp.900 (sembilan ratus rupiah). oleh karena itu diharapkan semoga kedepannya bisa ditegaskan dan dipertimbangkan kembali supaya pelaku penadahan yang melakukan atau melanggar pasal tersebut bisa merasa jera, kapok, tidak mengulanginya kembali, karena melihat sanksi mengenai penadahan ini masih ringan, maka peluang pelaku mungkin masih banyak, jika sanksi tersebut sudah setimpal dengan perbuatannya dan dendanya sudah sesuai, maka kemungkinan pelaku, atau masyarakat yang ingin melakukan kejahatan penadahan bisa berkurang untuk kedepannya sanksi ini di perbaiki.

\section{DAFTAR PUSTAKA}

Hamzah, A. (2011). KUHP \& KUHAP. Rineka Cipta, Jakarta.

Khoirunnisak, Erdianto, \& Diana, L. (2017). Pembuktian Tindak Pidana Penadahan Kendaraan Bermotor oleh Kepolisian Resor Kota Pekanbaru pada Tingkat Penyidikan. Jurnal Online Mahasiswa Fakultas Hukum, 3(2).

Lamintang, P. A. F. (1997). Dasar-dasar Hukum Pidana Indonesia. Citra Aditya Bakti, Bandung.

Lamintang, P. A. F. (2009). Delik-delik Khusus Kejahatan terhadap Harta Kekayaan. Sinar Grafika, Jakarta.

Lestiyana, \& Sudarti, E. (2020). Putusan Tentang Pemidanaan Terhadap Pelaku Tindak Pidana Penadahan. PAMPAS: Journal Of Criminal Law, 1(1), 68-78.

Mamahit, C. (2017). Aspek Hukum Pengaturan Tindak Pidana Penadahan dan Upaya Penanggulangannya di Indonesia. Jurnal Hukum Unsrat, 23(8), 69-81.

Prasetyo, T. (2010). Kriminalisasi dalam Hukum Pidana. Nusa Media, Bandung.

Putra, I. G. M. K. D., Tjatrayasa, I. M., \& Suardana, I. W. (2016). Pertanggungjawaban Pidana bagi Pembeli Barang Hasil Kejahatan ditinjau dari Pasal 480 KUHP Tentang Penadahan. Jurnal Kertha Wicara, 5(2), 1-5.

Rukmini, M. (2009). Aspek Hukum Pidana Dan Kriminologi (Sebuah Bunga Rampai). PT Alumni, Bandung.

Soesilo, R. (1984). Pokok-pokok Hukum Pidana Peraturan Umum dan Delik-delik Khusus. Politeia: Bogor. 